\title{
1,4,7-triazacyclononane-based bifunctional picolinate ligands for efficient copper complexation $^{\mathrm{i}}$
}

\author{
Amaury Guillou ${ }^{\mathrm{a}}$, Luís M. P. Lima ${ }^{\mathrm{b}}$, Mélissa Roger ${ }^{\mathrm{a}}, \underline{\text { David Esteban-Gómez }}{ }^{\mathrm{c}}$, Rita Delgado ${ }^{\mathrm{b}}, \underline{\text { Carlos }}$ \\ $\underline{\text { Platas-Iglesias }}^{\mathrm{c}}$, Véronique Patinec ${ }^{\mathrm{a}^{*}}$, Raphaël Tripier $^{\mathrm{a}}$ \\ ${ }^{\text {a }}$ Université de Bretagne Occidentale, UMR-CNRS 6521, 6 avenue Victor le Gorgeu, C.S. 93837, 29238 Brest \\ Cedex 3, France \\ ${ }^{\mathrm{b}}$ Instituto de Tecnologia Química e Biológica António Xavier, Universidade Nova de Lisboa, Av. da República, \\ 2780-157 Oeiras, Portugal \\ ${ }^{\mathrm{c}}$ Universidade da Coruña, Centro de Investigacións Científicas Avanzadas (CICA) and Departamento de Química \\ Fundamental, Facultade de Ciencias, 15071 A Coruña, Galicia, Spain
}

European Journal of Inorganic Chemistry, volume 2017, issue 18, pages 2435-2443, 10 May 2017 Received 17 February 2017, version of record online 11 May 2017, issue online 11 May 2017

This is the peer reviewed version of the following article:

Guillou, A., Lima, L. M., Roger, M., Esteban-Gómez, D., Delgado, R., Platas-Iglesias, C., Patinec, V. and Tripier, R. (2017), 1,4,7-Triazacyclononane-Based Bifunctional Picolinate Ligands for Efficient Copper Complexation. Eur. J. Inorg. Chem., 2017: 2435-2443

which has been published in final form at https://doi.org/10.1002/ejic.201700176. This article may be used for non-commercial purposes in accordance with Wiley Terms and Conditions for Use of Self-Archived Versions.

\begin{abstract}
Three 1,4,7-triazacyclononane-based (tacn-based) ligands containing picolyl and picolinate pendant arms (no3py, no2pa1py, and no3pa) were synthesized, and their copper(II) complexation properties were studied to evaluate their potentials as chelators for copper radioisotopes. The thermodynamic stability constants of the complexes were determined by potentiometric titrations. These studies evidenced the formation of mononuclear species for no3py and mono- and dinuclear species for no2pa1py and no3pa. The pCu values decreased as the number of carboxypicolyl arms increased. The $\left[\mathrm{Cu}(\text { no3py) }]^{2+}\right.$ complex presented a very high stability constant $\left(\log K_{\mathrm{CuL}}=27.4\right)$ and a very high selectivity towards $\mathrm{Zn}^{2+}$ ions $\left(\log K_{\mathrm{ZnL}}=17.25\right)$. Vis/NIR (NIR = near-infrared) absorption and electron paramagnetic resonance (EPR) spectroscopy indicated that the three complexes present distorted octahedral geometries with two paramagnetic species, which were identified as the $\Delta(\delta \delta \delta)$ and $\Lambda(\delta \delta \delta)$ isomers [and their corresponding enantiomeric forms $\Lambda(\lambda \lambda \lambda)$ and $\Delta(\lambda \lambda \lambda)$ ] by DFT calculations. The electrochemical properties were investigated by cyclic voltammetry, which revealed quasireversible behavior for the $\left[\mathrm{Cu}(\text { no3py) }]^{2+}\right.$ complex but irreversible $\mathrm{Cu}^{2+} / \mathrm{Cu}^{+}$systems for $\left[\mathrm{Cu}(\right.$ no2pa1py) $]$ and $\left[\mathrm{Cu}(\text { no3pa) }]^{-}\right.$.
\end{abstract}

Keywords: copper; macrocyclic ligands; $\mathrm{N}$ ligands; imaging agents; potentiometry

\footnotetext{
*veronique.patinec@univ-brest.fr
} 


\section{Introduction}

Radioelements are attracting growing interest from the scientific community because of their continuously increasing applications in radiochemistry and nuclear medicine ${ }^{[1]}$ Among the available radioelements, metallic radionuclides possess attractive features with high potential benefits in clinical medicine through the supply of adjustable radiopharmaceuticals. ${ }^{[2]}$ Thus, a large choice of radionuclides with different half-lives are available for in vivo applications. Furthermore, the different coordination properties of metal ions also facilitate a large choice of sequestrating chelators for the encapsulation of the metallic radioisotope. In addition to the chelating unit, radiopharmaceuticals usually contain an active functional group suitable for conjugation to a targeting biovector such as a peptide or an antibody. The development of such bifunctional chelating agents (BCAs) often requires the cooperation of scientists with different areas of expertise (i.e., coordination chemistry, radiochemistry, and biochemistry). ${ }^{[3]}$

Among the copper radioisotopes, ${ }^{64} \mathrm{Cu}\left(\beta^{+}, t_{1 / 2}=12.7 \mathrm{~h}\right)$ appears to be a particular good candidate for positron emission tomography (PET) imaging owing to its relatively long decay and the possibility to form an interesting theranostic pair with the $\beta^{-}$emitter ${ }^{67} \mathrm{Cu}$ isotope $\left(\beta^{-}, t_{1 / 2}=62 \mathrm{~h}\right)$. Among the numerous compounds used as chelators for ${ }^{64} \mathrm{Cu}$ labeling, 1,4,7-triazacyclononane-1,4,7-triacetic acid $\left(\mathrm{H}_{3}\right.$ nota; Scheme 1) has been the subject of intense research efforts, as it forms complexes with in vivo stabilities higher than those of 1,4,7,10-tetraazacyclododecane-1,4,7,10-tetraacetic acid $\left(\mathrm{H}_{4} \mathrm{dota}\right)$ and 1,4,8,11tetraazacyclotetradecane-1,4,8,11-tetraacetic acid $\left(\mathrm{H}_{4}\right.$ teta) analogues. ${ }^{[4]}$ Commercially available nota derivatives have been developed owing to the interesting properties of this ligand scaffold for the envisaged applications.<smiles>O=C(O)CN1CCN(CC(=O)O)CCN(CC(=O)O)CC1</smiles>

$\mathrm{H}_{3}$ nota<smiles>O=C(O)c1cccc(CN2CCN(Cc3ccccn3)CCN(Cc3ccccn3)CC2)n1</smiles>

Hno1pa2py<smiles>O=C(O)CN1CCN(Cc2ccccn2)CCN(Cc2ccccn2)CC1</smiles>

Hno1a2py

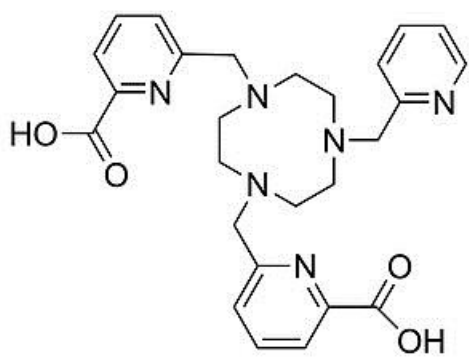

$\mathrm{H}_{2}$ no2pa1py

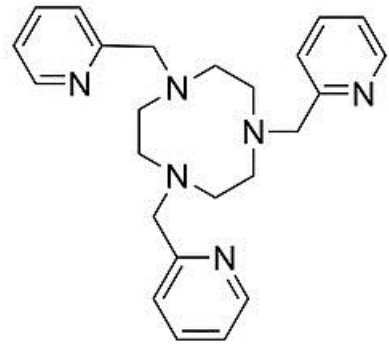

no3py

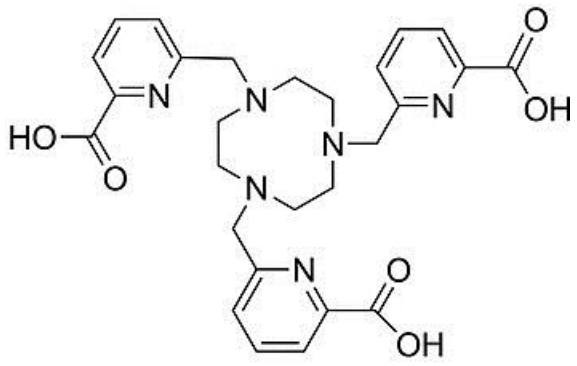

$\mathrm{H}_{3}$ no3pa

Scheme 1. Structures of the tacn derivatives discussed in this work.

As the chelating unit of the BCA plays a crucial role in the properties of the radiopharmaceutical, many ligands have been designed, and their "cold" copper(II) complexation properties have been investigated. An ideal chelator for this specific application should be prepared readily from commercially available materials and show fast complexation kinetics as well as high thermodynamic and kinetic stability in vivo to avoid the 
release of the toxic metal ion. ${ }^{[5]}$ Given the borderline character of the $\mathrm{Cu}^{2+}$ cation within the Pearson classification, ligands designed for its efficient complexation usually contain oxygen and nitrogen donor atoms, which are often provided by acyclic and cyclic polyamines with pyridyl, acetate, or methylenephosphonate arms. Thus, 1,4,7-triazacyclononane (tacn) derivatives containing methylenephosphonate ${ }^{[6,7]}$ or picolyl ${ }^{[8]}$ arms to replace pendant carboxylic acids have been reported.

Recently, we described the tacn-based ligand Hno1pa2py, which contains two picolyl and one carboxypicolyl pendant arms for complexation with $\mathrm{Cu}^{2+}$ cations. ${ }^{[9]}$ This complex exhibited fast complexation kinetics, high thermodynamic stability, kinetic inertness in acidic media, and stability under reducing conditions. The ${ }^{64} \mathrm{Cu}$ labeling of Hno1pa2py was also fast and efficient, which opens interesting perspectives for the development of bifunctional agents based on this chelator. Thus, we envisaged that the family of tacn-based ligands containing picolyl and carboxypicolyl pendants could be expanded. To this aim, herein we report the synthesis of no3py, $\mathrm{H}_{2}$ no2pa1py, and $\mathrm{H}_{3}$ no3pa (Scheme 1), as well as a detailed study of the thermodynamic stabilities of their complexes with $\mathrm{Cu}^{2+}$ and $\mathrm{Zn}^{2+}$ ions. The structures of the complexes in solution were investigated through a combination of electron paramagnetic resonance (EPR) and UV/Vis spectroscopy, cyclic voltammetry, and DFT calculations.

\section{Results and Discussion}

\section{Synthesis of the Ligands and Complexes}

Compounds no3py and no3pa were synthesized by the direct alkylation of tacn in acetonitrile with 2(chloromethyl)pyridine and methyl 6-(chloromethyl)pyridine-2-carboxylate, ${ }^{[10]}$ respectively. A yield of $50 \%$ was reported for a synthesis of $\mathrm{H}_{3}$ no3py involving the alkylation of tacn in aqueous solution. ${ }^{[11]}$ The procedure reported here afforded no3py with a yield of more than $80 \%$ after purification by column chromatography, and this yield represents a significant improvement over the literature value. The methyl ester derivative of $\mathrm{H}_{3}$ no3pa was isolated after purification and subsequently hydrolyzed quantitatively with $6 \mathrm{~m} \mathrm{HCl}$ for a global yield of $57 \%$, which is also somewhat higher than the value reported for the basic hydrolysis of the intermediate ethyl ester $(51 \%){ }^{[12]}$

The new chelator $\mathrm{H}_{2}$ no2pa1py was obtained in a global yield of approximately $53 \%$ (the remaining solvents precluded the calculation of the true yield; see the Supporting Information) through a modification of the synthetic procedure of $\mathrm{Hno1pa2py}{ }^{[9]}$ by the well-known orthoamide method (Scheme 2). 2(Chloromethyl)pyridine (1 equiv.) was added to the orthoamide intermediate $\mathbf{1}$ to give the corresponding mono(ammonium) salt $\mathbf{2}$, the acidic hydrolysis of which led to the formation of 1-[(2-pyridyl)methyl]tacn (3) in $87 \%$ yield, and two secondary amino functions remained free to react with methyl 6(chloromethyl)pyridine-2-carboxylate (2 equiv.). The alkylation reaction yielded 4 in good yield (ca. $70 \%$ ), and the quantitative hydrolysis of the methyl ester functions was achieved with $6 \mathrm{~m} \mathrm{HCl}$. The copper(II) complexes were synthesized by reaction of the ligands with copper(II) perchlorate in aqueous media at $\mathrm{pH} \approx$ 6 , and all of the complexes were isolated as blue solids.

\section{$\underline{\text { Acid/Base Properties }}$}

The protonation constants of the ligands were determined by potentiometric titrations in aqueous solutions at $25.0{ }^{\circ} \mathrm{C}$ and $I=0.10 \mathrm{~m}$ in $\mathrm{KNO}_{3}$ (Table 1). The compounds display an increasing number of basic centers consisting of amino, pyridine, and carboxylate functions; no3py has a total of six potential protonation sites, $\mathrm{H}_{2}$ no2pa1py has eight, and $\mathrm{H}_{3}$ no3pa has nine. For all of the compounds, the two most basic centers correspond to the macrocyclic amino groups, as is usually observed for tacn derivatives. ${ }^{[13]}$ All of the subsequent protonation constants correspond to the protonation of a growing number of pyridine and carboxylate groups of the pendant arms. 


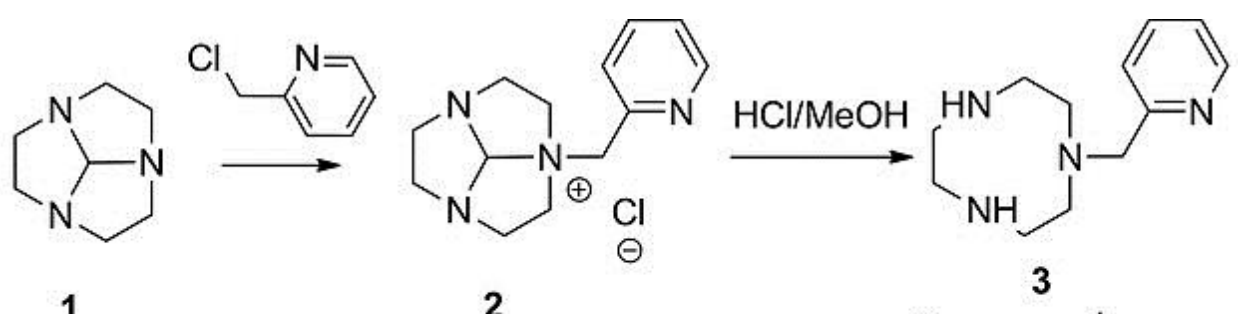<smiles>COC(=O)c1cccc(CN2CCN(Cc3ccccn3)CCN(Cc3cccc(C(=O)OC)n3)CCN(Cc3cccc(C(=O)OC)n3)CC2)n1</smiles>

Scheme 2. Synthesis of $\mathrm{H}_{2}$ no2pa1py.

Table 1. Stepwise $\left(\log K_{i}^{\mathrm{H}}\right)$ protonation constants of no3py, $\mathrm{H}_{2}$ no2pa1py, $\mathrm{H}_{3}$ no3pa, and related ligands in aqueous solutions at $25.0^{\circ} \mathrm{C}$ and $I=0.10 \mathrm{~m}$ in $\mathrm{KNO}_{3}$

\begin{tabular}{|c|c|c|c|c|c|}
\hline Equilibrium reaction $^{[a]}$ & no3py ${ }^{[b]}$ & Hno1pa2py ${ }^{[c]}$ & $\begin{array}{r}\mathrm{H}_{2} \mathrm{no} \mathrm{pa} \mathrm{py}^{[\mathrm{b}]} \\
\log K\end{array}$ & $\mathrm{H}_{3}$ no3pa & $\mathrm{H}_{3}$ nota \\
\hline $\mathrm{L}+\mathrm{H}^{+} \rightleftarrows \mathrm{HL}$ & $11.07(2)$ & 10.61 & $11.10(1)$ & $10.72(1),{ }^{[b]} 10.8^{[\mathrm{d}]}$ & $11.96{ }^{\left[{ }^{[\mathrm{e}]}\right.} 11.73^{[\mathrm{f}]}$ \\
\hline $\mathrm{HL}+\mathrm{H}^{+} \rightleftarrows \mathrm{H}_{2} \mathrm{~L}$ & $5.07(2)$ & 5.25 & $5.53(2)$ & $5.62(1),{ }^{[\mathrm{b}]} 5.7^{[\mathrm{d}]}$ & $5.655^{[\mathrm{ee}]} 5.74^{[\mathrm{ff}]}$ \\
\hline $\mathrm{H}_{2} \mathrm{~L}+\mathrm{H}^{+} \rightleftarrows \mathrm{H}_{3} \mathrm{~L}$ & $3.55(2)$ & 3.69 & $4.22(2)$ & $3.85(1),{ }^{[\mathrm{b}]} 3.8^{[\mathrm{d}]}$ & $3.17,{ }^{[\mathrm{e}]} 3.16^{[\mathrm{f]}]}$ \\
\hline $\mathrm{H}_{3} \mathrm{~L}+\mathrm{H}^{+} \rightleftarrows \mathrm{H}_{4} \mathrm{~L}$ & $1.78(3)$ & 1.61 & $2.78(2)$ & $2.81(1),{ }^{[\mathrm{b}]} 3.0^{[\mathrm{d}]}$ & $1.71,{ }^{[\mathrm{e}]} 1.96^{[\mathrm{f]}]}$ \\
\hline $\mathrm{H}_{4} \mathrm{~L}+\mathrm{H}^{+} \rightleftarrows \mathrm{H}_{5} \mathrm{~L}$ & - & - & $1.79(5)$ & $2.51(3),{ }^{[\mathrm{b}]} 2.5^{[\mathrm{d}]}$ & - \\
\hline $\mathrm{H}_{5} \mathrm{~L}+\mathrm{H}^{+} \rightleftarrows \mathrm{H}_{6} \mathrm{~L}$ & - & - & - & $1.86(8)^{[\mathrm{b}]}$ & - \\
\hline
\end{tabular}

[a] The charges of the species are omitted for clarity. [b] This work; the values in parentheses are the standard deviations in the last significant figure. [c] Ref. 9. [d] Ref. 17, 0.1 m KCl. [e] Ref. 15, $0.1 \mathrm{~m} \mathrm{KCl}$. [f] Ref. 16, $0.1 \mathrm{~m} \mathrm{NaNO}_{3}$.

Previous studies have shown that picolinate groups usually undergo protonation at the carboxylate function rather than at the nitrogen atom of the pyridine unit. ${ }^{[14]}$ For $\mathrm{H}_{3}$ no3pa, an additional sixth constant was detected and could be related to a third macrocyclic amino group. Considering the different numbers of protonation constants determined for these compounds, the overall basicity increases with the increasing number of picolinate pendant arms, and the basicities of the macrocyclic amine groups are quite similar for all compounds. 


\section{Thermodynamic Stability Constants}

The stability constants of the complexes of the ligands with $\mathrm{Cu}^{2+}$ and $\mathrm{Zn}^{2+}$ cations were also determined by potentiometric titrations in aqueous solutions at $25.0{ }^{\circ} \mathrm{C}$ and $I=0.10 \mathrm{~m}$ in $\mathrm{KNO}_{3}$ (Table 2). The very high stability constant of the complex formed between no3py and $\mathrm{Cu}^{2+}$ ions required an out-of-cell competition experiment with 1,4,8,11-tetraazacyclotetradecane (cyclam) as a competitor ligand, whereas determinations could be made by direct titrations in all other cases. The equilibria studies demonstrated that both $\mathrm{H}_{2}$ no2pa1py and $\mathrm{H}_{3}$ no3pa exhibit mono- and dinuclear complex species with $\mathrm{Cu}^{2+}$ and $\mathrm{Zn}^{2+}$ cations in the presence of more than 1 equiv. of each cation, whereas no3py forms only mononuclear complexes. This fact is clearly related to the presence of additional donor atoms in the structures of the $\mathrm{H}_{2}$ no2pa1py and $\mathrm{H}_{3}$ no3pa ligands. The stabilities of the mononuclear $\mathrm{Cu}^{2+}$ complexes decrease as the number of picolinate pendant arms increases. The stabilities of the mononuclear $\mathrm{Zn}^{2+}$ complexes are of the same order for all ligands and did not display a marked trend. From a comparison of the pM values calculated for the different complexes, which give a more reliable measure of their relative stability, it is clear that the $\mathrm{pCu}$ values decrease as the number of picolinate pendant arms increases, whereas the $\mathrm{pZn}$ values are rather close for all of the complexes. As a consequence, there is an important decrease in the selectivity for $\mathrm{Cu}^{2+}$ over $\mathrm{Zn}^{2+}$ cations for the ligands with more picolinate pendant arms. However, the outstandingly high selectivity found for no3py is more noteworthy. Overall, it is evident that no3py forms copper(II) complexes of very high stability and very high selectivity over $\mathrm{Zn}^{2+}$ cations and, therefore, shows a remarkable behavior that surpasses that reported for $\mathrm{H}_{3}$ nota.

Table 2. Stepwise (log $K_{\mathrm{M}_{m} \mathrm{H}_{h} \mathrm{~L}}$ ) stability constants and $\mathrm{pM}$ values for the copper(II) and zinc(II) complexes of no3py, $\mathrm{H}_{2}$ no2pa1py, $\mathrm{H}_{3}$ no3pa, and related ligands in aqueous solutions at $25.0{ }^{\circ} \mathrm{C}$ and $I=0.10 \mathrm{~m}$ in $\mathrm{KNO}_{3}$

\begin{tabular}{|c|c|c|c|c|c|}
\hline Equilibrium reaction $^{[\mathrm{a}]}$ & no3py ${ }^{[b]}$ & Hno1pa2py ${ }^{[c]}$ & $\mathrm{H}_{2} \mathrm{no} \mathrm{pa} \mathrm{py}^{[\mathrm{b}]}$ & $\mathrm{H}_{3} \mathrm{no} \mathrm{pa}^{[\mathrm{b}]}$ & $\mathrm{H}_{3}$ nota \\
\hline \multicolumn{6}{|c|}{$\log K_{\mathrm{M}_{m} \mathrm{H}_{h} \mathrm{~L}}$} \\
\hline $\mathrm{Cu}^{2+}+\mathrm{L} \rightleftarrows \mathrm{CuL}$ & $27.4(1)$ & 20.96 & $18.32(2)$ & $16.21(5)$ & $21.63^{[\mathrm{d}]}$ \\
\hline $\mathrm{CuL}+\mathrm{H}^{+} \rightleftarrows \mathrm{CuHL}$ & $2.13(1)$ & 2.71 & $2.68(1)$ & - & $2.74^{[\mathrm{d}]}$ \\
\hline $\mathrm{CuHL}+\mathrm{H}^{+} \rightleftarrows \mathrm{CuH}_{2} \mathrm{~L}$ & - & - & $1.68(2)$ & - & - \\
\hline $\mathrm{CuL}(\mathrm{OH})+\mathrm{H}^{+} \rightleftarrows \mathrm{CuL}$ & $11.65(3)$ & 11.31 & - & - & - \\
\hline $\mathrm{Cu}^{2+}+\mathrm{CuL} \rightleftarrows \mathrm{Cu}_{2} \mathrm{~L}$ & - & - & - & $5.16(4)$ & - \\
\hline $\mathrm{Cu}_{2} \mathrm{~L}(\mathrm{OH})+\mathrm{H}^{+} \rightleftarrows \mathrm{Cu}_{2} \mathrm{~L}$ & - & - & - & $7.35(2)$ & - \\
\hline $\mathrm{Cu}_{2} \mathrm{~L}(\mathrm{OH})_{2}+\mathrm{H}^{+} \rightleftarrows \mathrm{Cu}_{2} \mathrm{~L}(\mathrm{OH})$ & - & - & $8.22(4)$ & $8.75(2)$ & - \\
\hline $\mathrm{Zn}^{2+}+\mathrm{L} \rightleftarrows \mathrm{ZnL}$ & $17.25(4)$ & 16.49 & $17.59(4)$ & $15.95(6)$ & $18.30^{[\mathrm{e}]}$ \\
\hline $\mathrm{ZnL}+\mathrm{H}^{+} \rightleftarrows \mathrm{ZnHL}$ & $1.91(6)$ & 2.51 & $3.77(2)$ & $3.99(6)$ & - \\
\hline $\mathrm{ZnHL}+\mathrm{H}^{+} \rightleftarrows \mathrm{ZnH}_{2} \mathrm{~L}$ & - & - & $1.91(2)$ & $2.47(1)$ & - \\
\hline $\mathrm{ZnL}(\mathrm{OH})+\mathrm{H}^{+} \rightleftarrows \mathrm{ZnL}$ & $11.59(4)$ & 11.19 & - & $10.69(4)$ & - \\
\hline $\mathrm{Zn}^{2+}+\mathrm{ZnL} \rightleftarrows \mathrm{Zn}_{2} \mathrm{~L}$ & - & - & $2.58(7)$ & $3.20(9)$ & - \\
\hline \multirow[t]{2}{*}{$\mathrm{Zn}_{2} \mathrm{~L}(\mathrm{OH})+\mathrm{H}^{+} \rightleftarrows \mathrm{Zn}^{2} \mathrm{~L}$} & - & - & $8.48(9)$ & - & - \\
\hline & \multicolumn{4}{|c|}{ pM values } & \\
\hline $\mathrm{pCu}^{[f]}$ & 23.70 & 17.75 & 14.62 & 12.88 & $17.61^{[\mathrm{c}]}$ \\
\hline $\mathrm{pZn}^{[\mathrm{f}]}$ & 13.58 & 13.28 & 13.88 & 12.63 & $14.28^{[\mathrm{c}]}$ \\
\hline
\end{tabular}

[a] The charges of the ligand and complex species are omitted for clarity. [b] This work; the values in parentheses are the standard deviations in the last significant figure. [c] Ref. 9. [d] Ref. 16. [e] Ref. 15. [f] Calculated at $C_{\text {ligand }}=2 \times C_{\text {cation }}=2.0 \times 10^{-5} \mathrm{~m}$ and $\mathrm{pH} 7.4$. 


\section{$\underline{\text { Structural Studies }}$}

The copper(II) complexes of the ligands were characterized in solution by Vis/NIR (NIR = near-infrared) absorption spectroscopy (Table 3). All of the copper(II) complexes exhibit the usual $\mathrm{d}-\mathrm{d}$ transition band at $\lambda \approx 670-690 \mathrm{~nm}$, and the complexes of $\mathrm{H}_{2}$ no2pa1py and $\mathrm{H}_{3}$ no3pa display an additional NIR band at $\lambda=$ 1200 and $1100 \mathrm{~nm}$, respectively. These spectra are indicative of tetragonally distorted octahedral coordination environments. ${ }^{[18]}$

Table 3. Vis/NIR and EPR spectroscopic parameters obtained for the copper(II) complexes in aqueous solution

\begin{tabular}{|c|c|c|c|c|c|c|c|c|c|}
\hline Complex & $\lambda_{\max }(\varepsilon)^{[\mathrm{a}]}$ & Isomer [\%] & & $g_{x}$ & $g_{y}$ & $g_{z}$ & $A_{x}^{[b]}$ & $A_{y}{ }^{[b]}$ & $A_{z}^{[b]}$ \\
\hline \multirow[t]{6}{*}{$\mathrm{Cu}(\text { no3py })^{2+}$} & \multirow[t]{6}{*}{$688(127)$} & \multirow[t]{3}{*}{$\Delta(\delta \delta \delta)(76)$} & exp. & 2.060 & 2.070 & 2.240 & 16 & 11 & 160.2 \\
\hline & & & calcd. $^{[c]}$ & 2.020 & 2.090 & 2.139 & $32^{[\mathrm{e}]}$ & 80 & $142.2^{[\mathrm{e}]}$ \\
\hline & & & calcd. $^{[\mathrm{d}]}$ & 2.026 & 2.119 & 2.186 & $34^{[\mathrm{e}]}$ & 88 & $156.8^{[\mathrm{e}]}$ \\
\hline & & \multirow[t]{3}{*}{$\Lambda(\delta \delta \delta)(24)$} & exp. & 2.052 & 2.054 & 2.209 & $<5$ & $<5$ & 172.9 \\
\hline & & & calcd. $^{[c]}$ & 2.046 & 2.050 & 2.141 & 22 & 29 & $171.5^{[\mathrm{e}]}$ \\
\hline & & & calcd. $^{[\mathrm{d}]}$ & 2.060 & 2.065 & 2.186 & 23 & 31 & $189.1^{[\mathrm{e}]}$ \\
\hline \multirow[t]{6}{*}{$\mathrm{Cu}($ no2pa1py) } & $675(121)$ & \multirow[t]{3}{*}{$\Delta(\delta \delta \delta)(73)$} & exp. & 2.035 & 2.097 & 2.225 & 14 & 46 & 150.4 \\
\hline & $1200(56)$ & & calcd. $^{[\mathrm{c}]}$ & 2.026 & 2.081 & 2.140 & $13^{[\mathrm{e}]}$ & 72 & 151.1 \\
\hline & & & calcd. $^{[\mathrm{d}]}$ & 2.034 & 2.106 & 2.186 & $14^{[\mathrm{e}]}$ & 78 & $167.5^{[\mathrm{e}]}$ \\
\hline & & \multirow[t]{3}{*}{$\Lambda(\delta \delta \delta)(27)$} & exp. & 2.038 & 2.071 & 2.209 & 49 & $<5$ & 189.1 \\
\hline & & & calcd. $^{[\mathrm{c}]}$ & 2.038 & 2.060 & 2.141 & 12 & 43 & $169.1^{[\mathrm{e}]}$ \\
\hline & & & calcd. $^{[\mathrm{d}]}$ & 2.050 & 2.079 & 2.186 & 11 & 46 & $186.7^{[\mathrm{e}]}$ \\
\hline \multirow[t]{6}{*}{$\mathrm{Cu}(\mathrm{no} 3 \mathrm{pa})^{-}$} & $678(120)$ & \multirow[t]{3}{*}{$\Delta(\delta \delta \delta)(75)$} & exp. & 2.042 & 2.091 & 2.233 & 55 & 29 & 130.6 \\
\hline & $1100(45)$ & & calcd. $^{[c]}$ & 2.032 & 2.054 & 2.132 & 7 & 56 & $161.7^{[\mathrm{e}]}$ \\
\hline & & & calcd. $^{[\mathrm{d}]}$ & 2.054 & 2.060 & 2.176 & 18 & 32 & $187.6^{[\mathrm{e}]}$ \\
\hline & & \multirow{3}{*}{$\Lambda(\delta \delta \delta)(25)$} & exp. & 2.047 & 2.069 & 2.220 & 19 & 27 & 159.6 \\
\hline & & & calcd. $^{[\mathrm{c}]}$ & 2.043 & 2.045 & 2.134 & 22 & 27 & $168.8^{[\mathrm{e}]}$ \\
\hline & & & calcd. $^{[\mathrm{d}]}$ & 2.040 & 2.072 & 2.171 & 3 & 61 & $179.1^{[\mathrm{e}]}$ \\
\hline
\end{tabular}

[a] $\lambda_{\max }[\mathrm{nm}] ; \varepsilon\left[\mathrm{m}^{-1} \mathrm{~cm}^{-1}\right]$. [b] Values of $A_{i} \times 10^{4} \mathrm{~cm}^{-1}$. [c] Calculated with the TPSSh functional. [d] Calculated with the TPSS0 functional. [e] Calculated as negative quantities.

The complexes in frozen aqueous solutions were also studied by X-band EPR spectroscopy. For the simulation of the EPR spectra of all of the complexes, two paramagnetic species had to be considered (see Table 3), similarly to the previous findings for $[\mathrm{Cu}(\text { no1pa2py })]^{+}{ }^{[9]}$ as single species do not reproduce the experimental spectra appropriately. The experimental EPR spectra are shown in Figure 1, whereas the simulations obtained are presented in the Supporting Information. EPR studies also revealed the presence of two complex species in solution for $[\mathrm{Cu}(\text { nota })]^{-[19]}$

Geometry optimizations of the $[\mathrm{Cu}(\mathrm{no} 3 \mathrm{py})]^{2+}$ complex in aqueous solution through DFT calculations (TPSSh/TZVP level) provided two energy minima, which correspond to the $\Delta(\delta \delta \delta)$ and $\Lambda(\delta \delta \delta)$ diastereoisomeric forms (Figure 2). Indeed, the coordination of the no3py ligand to the metal ion introduces two sources of helicity in the complex; one arises through the conformation of the three five-membered chelate rings formed upon the coordination of the tacn moiety (often denoted as $\delta$ or $\lambda$ ), and the second arises from the two possible orientations of the three pendant arms of the ligand (defined as $\Delta$ or $\Lambda$ ). ${ }^{[20]}$ As for complexes based on cyclen derivatives containing pendant arms, ${ }^{[21]}$ the combination of these two sources of 
chirality results in four possible stereoisomers, which exist as two enantiomeric pairs, that is, $\Delta(\delta \delta \delta) / \Lambda(\lambda \lambda \lambda)$ and $\Lambda(\delta \delta \delta) / \Delta(\lambda \lambda \lambda)$.

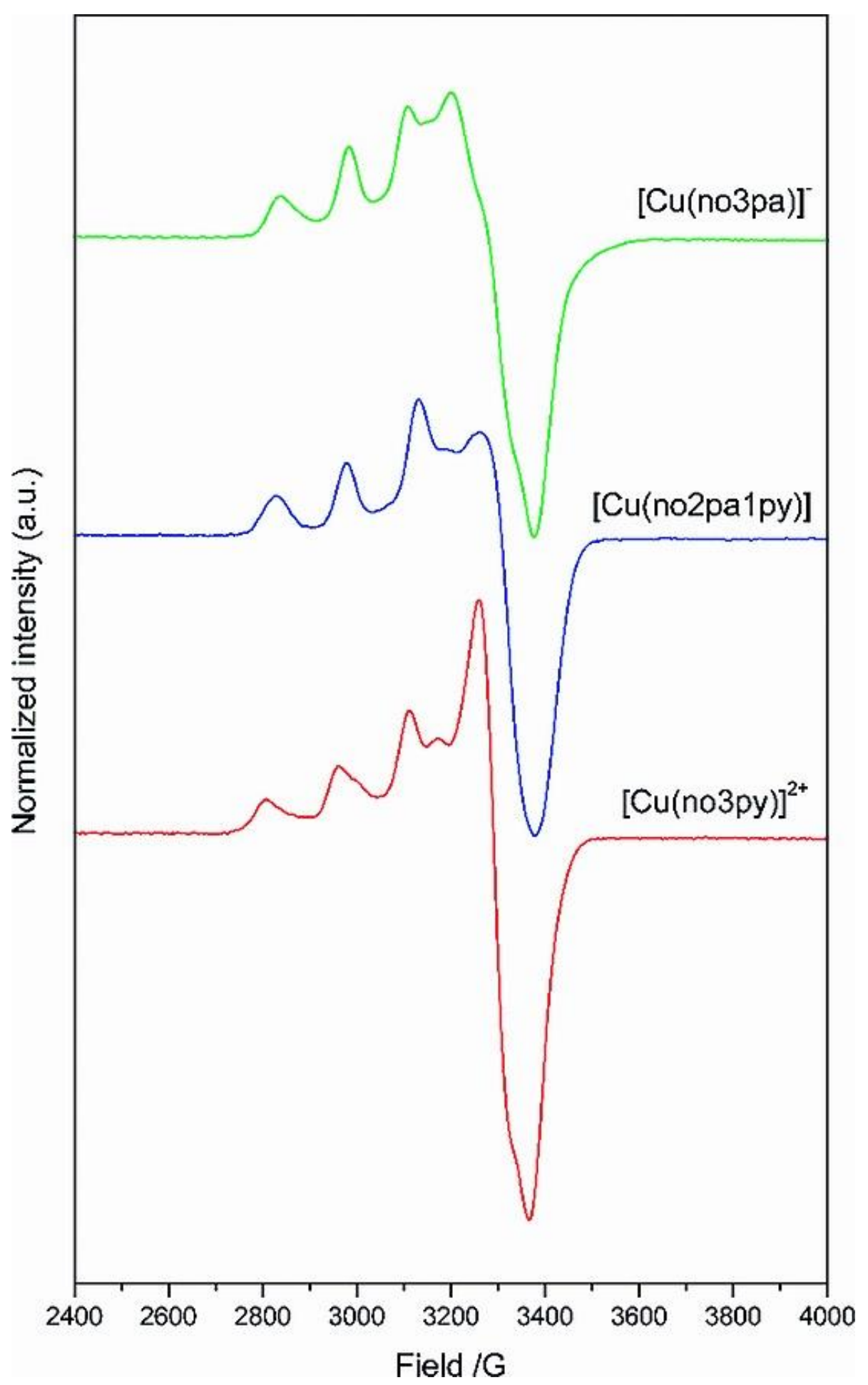

Figure 1. X-band EPR spectra of the copper(II) complexes in frozen aqueous solutions at $90 \mathrm{~K}$.

Our calculations provided a very small free-energy difference between the $\Delta(\delta \delta \delta)$ and $\Lambda(\delta \delta \delta)$ diastereoisomers, and the former one is favored by only $0.15 \mathrm{kcal} \mathrm{mol}^{-1}$. This is in line with the solid-state structures of the perchlorate salts of $[\mathrm{M}(\mathrm{no} 3 \mathrm{py})]^{2+}(\mathrm{M}=\mathrm{Cu}$ or $\mathrm{Zn})$, which present a $\Delta(\delta \delta \delta)$ conformation. ${ }^{[22]}$ 
Geometry optimizations performed for the $[\mathrm{Cu}(\mathrm{no} 2 \mathrm{pa} 1 \mathrm{py})]$ and $[\mathrm{Cu}(\mathrm{no} 3 \mathrm{pa})]^{-}$complexes also provided two energy minima corresponding to the $\Delta(\delta \delta \delta)$ and $\Lambda(\delta \delta \delta)$ isomers. The free-energy differences between these two isomers are small, and the $\Lambda(\delta \delta \delta)$ isomers are favored by 0.24 and $0.69 \mathrm{kcal} \mathrm{mol}^{-1}$ for [Cu(no2pa1py)] and $[\mathrm{Cu}(\mathrm{no} 3 \mathrm{pa})]^{-}$, respectively. All of the energy minima correspond to six-coordinate complexes with severely distorted octahedral geometries. The six donor atoms of the ligands coordinated to the metal ions in $[\mathrm{Cu}(\mathrm{no} 2 \mathrm{pa} 1 \mathrm{py})]$ and $[\mathrm{Cu}(\mathrm{no} 3 \mathrm{pa})]^{-}$are provided by the three nitrogen atoms of the tacn moiety, an oxygen atom and a nitrogen atom from a picolinate moiety, and a nitrogen atom of a pyridyl or picolinate unit. One of the pendant arms of the ligand remains uncoordinated in these complexes, in line with the results reported previously for $\left[\mathrm{Cu}(\text { no1pa2py) }]^{+} \cdot{ }^{[9]}\right.$ Thus, the introduction of picolinate pendant arms on the cyclic tacn structure provokes a change in the coordination mode of the ligand from $\mathrm{N}_{6}$ in $\left[\mathrm{Cu}(\mathrm{no} 3 \text { py) }]^{2+}\right.$ to $\mathrm{N}_{5} \mathrm{O}$. DFT calculations performed on the $[\mathrm{Cu}(\mathrm{no} 1 \mathrm{pa} 2 \mathrm{py})]^{+}$system provided free-energy differences that favor the $\mathrm{N}_{5} \mathrm{O}$ over $\mathrm{N}_{6}$ coordination by $4.8[\Delta(\delta \delta \delta)]$ and $3.8 \mathrm{kcal} \mathrm{mol}^{-1}[\Lambda(\delta \delta \delta)]$, and these energy differences are attributed to the steric hindrance introduced by the carboxylate group for the coordination of a neighboring pyridyl pendant arm.

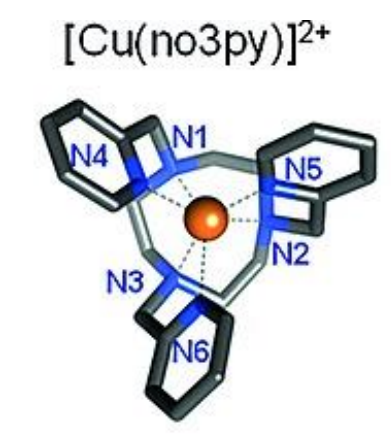

$\Delta(\delta \delta \delta)$

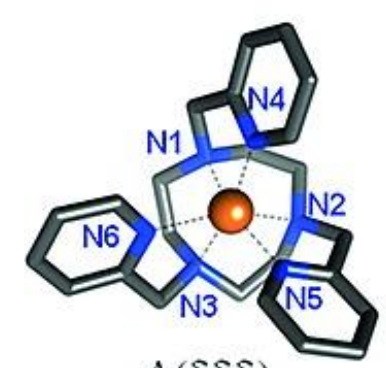

$\Lambda(\delta \delta \delta)$

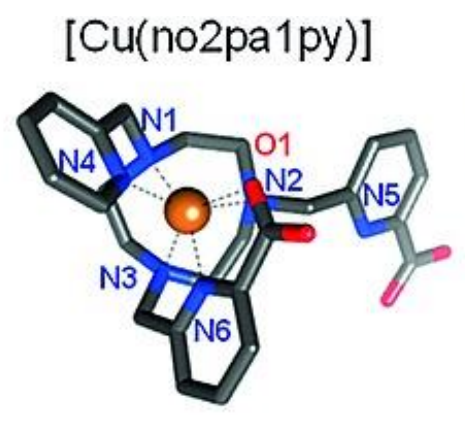

$\Delta(\delta \delta \delta)$

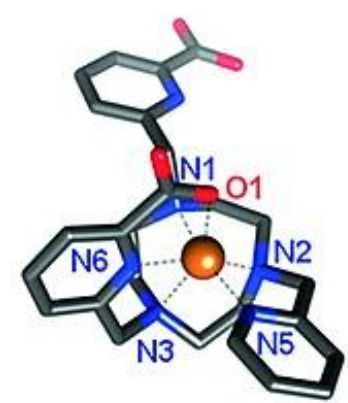

$\Lambda(\delta \delta \delta)$

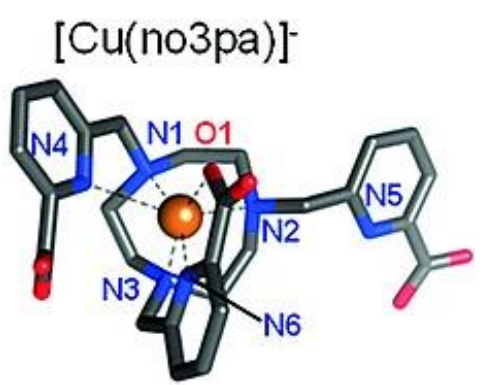

$\Delta(\delta \delta \delta)$

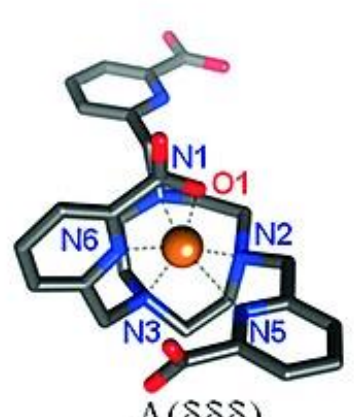

$\Lambda(\delta \delta \delta)$

Figure 2. Optimized geometries calculated in aqueous solution at the TPSSh/TZVP level.

The small free-energy differences obtained from DFT calculations for the $\Delta(\delta \delta \delta)$ and $\Lambda(\delta \delta \delta)$ isomers suggest that both of them may be present in solution with sizeable populations, in agreement with the experimentally observed EPR spectra. The bond lengths of the metal coordination environments calculated for $\left[\mathrm{Cu}(\text { no1pa2py) }]^{+}\right.$and $\left[\mathrm{Cu}(\right.$ no2pa1py) $]$ are quite similar but very different to those of $[\mathrm{Cu}(\text { no3pa })]^{-}$(see the Supporting Information). These results suggest that the replacement of the pyridyl group of no2pa1py ${ }^{2-}$ by a picolinate unit introduces a significant degree of steric constraint for the coordination of the ligand to the metal ion.

The EPR parameters of the tacn derivatives investigated in this work were further analyzed by DFT calculations of the $g$ and $A$ tensors (see Computational Details section below for more information). These calculations used the geometries of the $\Delta(\delta \delta \delta)$ and $\Lambda(\delta \delta \delta)$ isomers of the different complexes optimized at 
the TPSSh/TZVP level. Our calculations with the TPSSh functional provided a $g$ tensor with $g_{z}>g_{y}>g_{x}$ and $g_{x} \geq 2.03$, in agreement with the parameters obtained from the simulation of the experimental EPR spectra (Table 3). Thus, the calculated $g$ values reproduce well the trend observed experimentally, although $g_{z}$ is clearly underestimated by our DFT calculations. A similar study applied to tetragonal $\mathrm{Cu}^{2+}$ complexes also underestimated the calculated $g_{z}$ values but reproduced the observed experimental trends correctly. ${ }^{[23]}$ The calculated $A$ tensors give small values of $A_{x}$ and $A_{y}$, and the $A_{z}$ values are in reasonably good agreement with the experimental data. However, recent computational studies have shown that the accurate calculation of EPR parameters is a difficult task that depends very much on the functional used. ${ }^{[2]}$ More specifically, the accuracy of the calculated $g$ values improves considerably as the amount of exact exchange increases. ${ }^{[24]}$ For instance, calculations performed with the BHLYP functional (50\% exact exchange) improve dramatically the agreement between the experimental and calculated $g_{z}$ values in comparison with the results obtained with the TPSSh functional (10\% exchange). However, the BHLYP functional overestimated the $A_{z}$ by a factor of 1.5 , whereas TPSSh provided calculated values in very good agreement with the experimental values. ${ }^{[25]}$ Thus, we calculated the $g$ and $A$ tensors with the TPSSO functional, which is a $25 \%$ exchange version of TPSSh. The results shown in Table 3 indicate that the TPSS0 functional improves considerably the agreement between the experimental and calculated $g$ values. Furthermore, the use of the TPSS0 functional also provides $A_{z}$ values in good agreement with the experimental ones, in contrast to BHLYP.

Given the similar EPR parameters obtained experimentally for the $\Delta(\delta \delta \delta)$ and $\Lambda(\delta \delta \delta)$ isomers of the different tacn derivatives, an unambiguous assignment of the EPR spectra is not possible. The major species observed in solution in the EPR spectra present $A_{z}$ values somewhat lower than those of the minor species (Table 3). The $A_{z}$ parameters calculated with the TPSSh and TPSS0 functionals for the $\Lambda(\delta \delta \delta)$ isomers of $[\mathrm{Cu}(\text { no3py })]^{2+},\left[\mathrm{Cu}(\right.$ no2pa1py) $]$ and $[\mathrm{Cu}(\text { no3pa })]^{-}$are higher than those obtained for the $\Delta(\delta \delta \delta)$ isomers. Thus, we have tentatively assigned the major species present in solution to the $\Delta(\delta \delta \delta)$ isomer.

\section{Electrochemical Properties}

The demetallation of radiolabeled pharmaceuticals in the body is an undesired phenomenon that leads to an increase of the background noise in PET imaging and increases the amount of unnecessary radiation in nontarget organs. ${ }^{[26]}$ The reduction of ${ }^{64} \mathrm{Cu}^{2+}$ ions into ${ }^{64} \mathrm{Cu}^{+}$ions by enzymes or bioreductants in biological media represents a potential pathway for the demetallation of ${ }^{64} \mathrm{Cu}$ radioconjugates. ${ }^{[27]}$ The study of the electrochemical stabilities of the cold copper(II) complexes by cyclic voltammetry provides a fast preliminary evaluation of the stabilities of the complexes upon reduction to the monovalent copper derivatives. Thus, we performed cyclic voltammetry studies of the copper(II) complexes in neutral aqueous solutions containing $0.1 \mathrm{~m}$ sodium acetate as the supporting electrolyte. The $[\mathrm{Cu}(\mathrm{no} 3 \mathrm{py})]^{2+}$ complex displays a quasireversible redox process with $E_{\mathrm{pc}}=-742 \mathrm{mV}$ and $E_{\mathrm{pa}}=-667 \mathrm{mV}\left(\Delta E_{\mathrm{p}}=75 \mathrm{mV}\right.$; Figure 3, Table 4), a behavior that is similar to that of $[\mathrm{Cu}(\mathrm{no} 1 \mathrm{pa} 2 \mathrm{py})]^{+}{ }^{[9]}$ The cyclic voltammograms recorded for $[\mathrm{Cu}(\mathrm{no} 2 \mathrm{pa} 1 \mathrm{py})]$ and $[\mathrm{Cu}(\mathrm{no} 3 \mathrm{pa})]^{-}$under the same conditions exhibited an increasing irreversible behavior reflected by an increased separation of the anodic and cathodic waves, and the values obtained were $E_{\mathrm{pc}}=-$ 692 and $-694 \mathrm{mV}$ and $E_{\mathrm{pa}}=-532$ and $-454 \mathrm{mV}$, respectively $\left(\Delta E_{\mathrm{p}}=160\right.$ and $\left.240 \mathrm{mV}\right)$. Thus, the $[\mathrm{Cu}(\text { no3py })]^{2+}$ and $\left[\mathrm{Cu}(\text { no1pa2py) }]^{+}\right.$complexes likely retain a similar coordination environment upon electrochemical reduction, whereas the increasing irreversibilities of the voltammograms for [Cu(no2pa1py)] and $\left[\mathrm{Cu}(\text { no3pa) }]^{-}\right.$suggest a change in the metal coordination spheres after the reduction from $\mathrm{Cu}^{2+}$ to $\mathrm{Cu}^{+}$. Overall, the half-wave reduction potential of the $[\mathrm{Cu}(\text { no3py })]^{2+}$ complex $\left(E_{1 / 2}{ }^{\text {red }}=-704 \mathrm{mV}\right)$ is even better than that reported for $[\mathrm{Cu}(\mathrm{no} 1 \mathrm{pa} 2 \mathrm{py})]^{+} .^{[9]}$ 


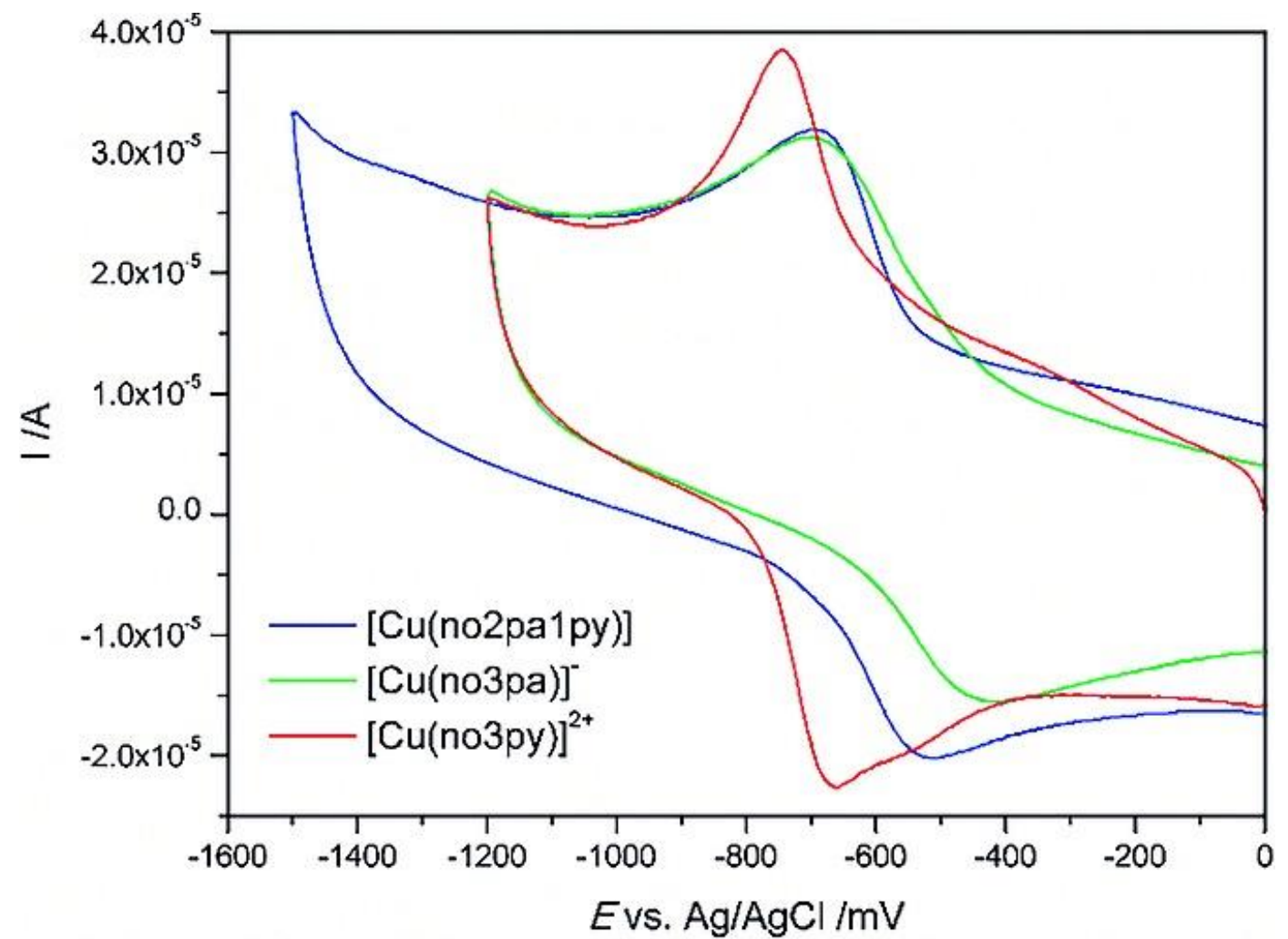

Figure 3. Cyclic voltammograms of the copper(II) complexes in aqueous $0.1 \mathrm{~m} \mathrm{NaOAc}$ solutions recorded at a scan rate of $100 \mathrm{mV} \mathrm{s}^{-1}$.

Table 4. Electrochemical data obtained for the copper(II) complexes ${ }^{[\mathrm{a}]}$

\begin{tabular}{lcccc}
\hline & no3py & no1pa2py $^{[\mathrm{b}]}$ & no2pa1py & no3pa \\
\hline$E_{\mathrm{pc}}[\mathrm{mV}]$ & -742 & -714 & -692 & -694 \\
$E_{\mathrm{pa}}[\mathrm{mV}]$ & -667 & -636 & -532 & -454 \\
$\Delta E_{\mathrm{p}}[\mathrm{mV}]$ & 75 & 78 & 160 & 240 \\
\hline
\end{tabular}

[a] In $0.1 \mathrm{~m} \mathrm{NaOAc}$ aqueous solutions with a glassy carbon electrode versus an $\mathrm{Ag} / \mathrm{AgCl}$ reference at a scan rate of $100 \mathrm{mV} \mathrm{s}^{-1}$. [b] Ref. 9.

\section{Conclusions}

The design of new copper(II) chelating macrocycles with suitable physicochemical properties (i.e., fast complexation, high thermodynamic stability, and stability upon reduction to $\mathrm{Cu}^{+}$) remains a challenge to the development of improved radiopharmaceuticals for applications in nuclear medicine. Among the different chelates reported to date, nota, a tacn-based ligand, is receiving particular attention owing to the in vivo stability of its ${ }^{64} \mathrm{Cu}$ conjugates, but its properties can still be improved. In this work, we investigated three complexes of $\mathrm{Cu}^{2+}$ with tacn-based ligands bearing picolinate and picolyl pendant arms to evaluate the impact that an increasing number of picolinate groups has on the physicochemical properties of the chelates. To this aim, the new ligand $\mathrm{H}_{2}$ no2pa1py was synthesized readily from tacn in five steps. The structural 
characterization of the copper(II) complexes in solution by Vis/NIR and EPR spectroscopy and DFT calculations revealed the presence of two isomers $[\Delta(\delta \delta \delta)$ and $\Lambda(\delta \delta \delta)]$, which exhibit distorted octahedral coordination around the metal center. One picolinate arm is coordinated to the metal center in $[\mathrm{Cu}(\mathrm{no} 1 \mathrm{pa} 2 \mathrm{py})]^{+},[\mathrm{Cu}(\mathrm{no} 2 \mathrm{pa} 1 \mathrm{py})]$, and $[\mathrm{Cu}(\mathrm{no} 3 \mathrm{pa})]^{-}$, whereas one of the picolinate or picolyl pendant arms is not involved in the coordination to the metal ion for all cases. The thermodynamic stability of the copper(II) complex with no3py is higher than that of nota, whereas Hno1pa2py and nota form complexes of comparable stability. However, an increase in the number of picolinate pendant arms in the ligand structure results in a noticeable drop of the stability constants and of the corresponding $\mathrm{pCu}$ values. The $[\mathrm{Cu}(\text { no3py })]^{2+}$ complex is particularly interesting owing to its very high stability constant $\left(\log K_{\mathrm{CuL}}=27.4\right)$, its outstandingly high selectivity for $\mathrm{Cu}^{2+}$ ions over $\mathrm{Zn}^{2+}$ ions $\left(\log K_{\mathrm{CuL}}-\log K_{\mathrm{ZnL}}=10.1\right)$, and its quasireversible cyclic voltammetry profile, which indicates that the complex does not dissociate on the time scale of the electrochemical experiments after reduction to the corresponding $\mathrm{Cu}^{+}$complex.

The present study has proven that the use of picolinyl arms to replace the acetic acid ones in nota represents a promising strategy to obtaining new BCAs for copper-based radiopharmaceuticals. The presence of a picolinate group characterized by one carboxylic acid function on the pyridine ring does not compromise the stability of the $\mathrm{Cu}^{2+}$ complex and offers a carboxylate function for potential conjugation. However, the introduction of more than one carboxypicolinyl pendant arm on the tacn macrocycle is clearly detrimental in terms of the stability of the complexes. Nevertheless, no3py appears to be particularly appealing for the development of new BCAs. Work is in progress in our laboratories to functionalize the aromatic ring with groups suitable for bioconjugation.

\section{Experimental Section}

\section{$\underline{\text { Materials and Methods }}$}

Reagents were purchased from ACROS Organics and Aldrich Chemical Co. 1,4,7-Triazacyclononane (tacn) was purchased from CheMatech (Dijon, France). 2-(Chloromethyl)pyridine was obtained through the basic treatment of the commercial 2-(chloromethyl)pyridine hydrochloride salt. Methyl 6-(chloromethyl)pyridine2-carboxylate was synthesized as described previously. ${ }^{[10]}$ Acetonitrile, tetrahydrofuran (THF), and water were distilled before use. Elemental analyses were performed at the Service de Microanalyse, CNRS, 69360 Solaize, France. The NMR spectra were recorded at the "Services communs" of the University of Brest. The ${ }^{1} \mathrm{H}$ and ${ }^{13} \mathrm{C}$ NMR spectra were recorded with Bruker Avance $500\left(500 \mathrm{MHz}\right.$ for $\left.{ }^{1} \mathrm{H}\right)$, Bruker Avance 400 (400 MHz for ${ }^{1} \mathrm{H}$ ), or Bruker AMX-3 300 (300 MHz for ${ }^{1} \mathrm{H}$ ) spectrophotometers, and the HRMS analyses were performed at the Institute of Analytic and Organic Chemistry IAOC in Orleans.

\section{1,4,7-Tris(2-picolinyl)-1,4,7-triazacyclononane (no3py)}

A solution of 2-(chloromethyl)pyridine $(1.14 \mathrm{~g}, 8.9 \mathrm{mmol})$ in acetonitrile $(5 \mathrm{~mL})$ was added to a solution of $\operatorname{tacn}(350 \mathrm{mg}, 2.7 \mathrm{mmol})$ in acetonitrile with an excess of sodium carbonate $(1.30 \mathrm{~g}, 9.5 \mathrm{mmol}, 3.5$ equiv.). The mixture was stirred at room temperature for $5 \mathrm{~d}$. The mixture was filtered, the solvent was evaporated, and the residue was purified by column chromatography on neutral alumina $\left(\mathrm{CH}_{2} \mathrm{Cl}_{2}\right.$ to $\left.\mathrm{CH}_{2} \mathrm{Cl}_{2} / \mathrm{MeOH}, 99: 1\right)$ to yield no3py as a brown oil $(900 \mathrm{mg}, 83 \%) .{ }^{1} \mathrm{H}$ NMR $\left(\mathrm{CD}_{3} \mathrm{Cl}, 300 \mathrm{MHz}\right): \delta=2.81\left(\mathrm{~m}, 12 \mathrm{H}, \mathrm{CH}_{2 \mathrm{tann}}\right), 3.75$ (s, $\left.6 \mathrm{H}, \mathrm{CH}_{2 \mathrm{py}}\right), 7.05\left(\mathrm{~m}, 3 \mathrm{H}, H_{\mathrm{ar}}\right), 7.42\left(\mathrm{~m}, 3 \mathrm{H}, H_{\mathrm{ar}}\right), 7.55\left(\mathrm{~m}, 3 \mathrm{H}, H_{\mathrm{ar}}\right), 8.42\left(\mathrm{~m}, 3 \mathrm{H}, H_{\mathrm{ar}}\right)$ ppm. ${ }^{13} \mathrm{C} \mathrm{NMR}$ $\left(\mathrm{CD}_{3} \mathrm{Cl}, 75.4 \mathrm{MHz}\right): \delta=55.7\left(\mathrm{CH}_{2 \mathrm{tacn}}\right), 64.6\left(\mathrm{CH}_{2 \mathrm{py}}\right), 122.2,122.8,136.3,148.8\left(C_{\mathrm{ar}}\right), 160.2\left(C_{\mathrm{ar}}\right) \mathrm{ppm}$.

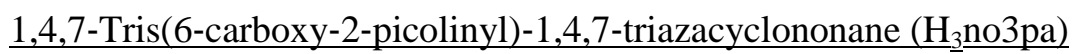

Methyl 6-(chloromethyl)pyridine-2-carboxylate $(1.0 \mathrm{~g}, 5.4 \mathrm{mmol})$ was added to a solution of tacn (232 $\mathrm{mg}$, $1.8 \mathrm{mmol}$ ) in acetonitrile with an excess of sodium carbonate $(870 \mathrm{mg}, 6.3 \mathrm{mmol}, 3.5$ equiv.). The mixture 
was stirred at room temperature for $5 \mathrm{~d}$. The mixture was filtered, the solvent was evaporated, and the residue was purified by column chromatography on neutral alumina $\left(\mathrm{CH}_{2} \mathrm{Cl}_{2}\right.$ to $\mathrm{CH}_{2} \mathrm{Cl}_{2} / \mathrm{EtOH}$ 98:2) to yield $\mathrm{H}_{3}$ no3pa as a brown oil $(710 \mathrm{mg}, 68 \%) .{ }^{1} \mathrm{H} \mathrm{NMR}\left(\mathrm{CDCl}_{3}, 300 \mathrm{MHz}\right): \delta=2.89$ (br. s, $\left.12 \mathrm{H}, \mathrm{CH}_{2 \text { tacn }}\right), 3.93$ (br. s, $\left.15 \mathrm{H}, \mathrm{CH}_{2 \mathrm{pic}}+\mathrm{OCH}_{3}\right), 7.76\left(\mathrm{~m}, 6 \mathrm{H}, H_{\mathrm{ar}}\right), 7.96\left(\mathrm{~d}, 3 \mathrm{H}, H_{\mathrm{ar}}\right)$ ppm. ${ }^{13} \mathrm{C} \mathrm{NMR}\left(\mathrm{CD}_{3} \mathrm{Cl}, 75.4 \mathrm{MHz}\right): \delta=$ $52.7\left(\mathrm{OCH}_{3}\right), 55.7\left(\mathrm{CH}_{2 \text { tacn }}\right), 64.4\left(\mathrm{CH}_{2 \mathrm{pic}}\right), 123.5,126.4,127.2\left(\mathrm{CH}_{\mathrm{ar}}\right), 147.2\left(C_{\mathrm{ar}}\right), 165.7(\mathrm{CO}) \mathrm{ppm}$. This resulting product was stirred in $6 \mathrm{~m}$ hydrochloric acid $(15 \mathrm{~mL})$ at $50{ }^{\circ} \mathrm{C}$ for $2 \mathrm{~d}$. After cooling, the solution was concentrated, and the residue was precipitated with diethyl ether to yield $\mathrm{H}_{3}$ no3pa as a white powder (84\%). ${ }^{1} \mathrm{H}$ NMR ( $\mathrm{D}_{2} \mathrm{O}, 300 \mathrm{MHz}$ ): $\delta=3.66$ (br. s, $12 \mathrm{H}, \mathrm{CH}_{2}$ tacn), 4.48 (br. s, $6 \mathrm{H}, \mathrm{CH}_{2 \text { pic }}$ ), 7.37 (d, 3 $\left.\mathrm{H}, H_{\mathrm{ar}}\right), 7.50\left(\mathrm{~d}, 3 \mathrm{H}, H_{\mathrm{ar}}\right), 7.70\left(\mathrm{~m}, 3 \mathrm{H}, H_{\mathrm{ar}}\right) \mathrm{ppm} .{ }^{13} \mathrm{C} \mathrm{NMR}\left(\mathrm{D}_{2} \mathrm{O}, 75.4 \mathrm{MHz}\right): \delta=54.0\left(\mathrm{CH}_{2} \operatorname{tacn}\right), 62.6$ $\left(\mathrm{CH}_{2 \mathrm{pic}}\right), 128.1,130.3,143.1\left(\mathrm{CH}_{\mathrm{ar}}\right), 147.9,155.3\left(C_{\mathrm{ar}}\right), 168.5(\mathrm{CO}) \mathrm{ppm}$.

\section{1-(2-Picolinyl)-1,4,7-triazacyclononane (3)}

(Dimethoxymethyl)dimethylamine (910 $\mu \mathrm{L}, 6.8 \mathrm{mmol}, 1$ equiv.) was added to a solution of tacn (880 $\mathrm{mg}$, $6.81 \mathrm{mmol})$ in chloroform $(2 \mathrm{~mL})$ and toluene $(8 \mathrm{~mL})$. The reaction mixture was stirred at room temperature for $12 \mathrm{~h}$. The solvent was evaporated under reduced pressure to yield a clear oil. This crude product was dissolved in THF $(20 \mathrm{~mL}$ ), and a solution of 2-(chloromethyl)pyridine (950 mg, $7.48 \mathrm{mmol}, 1.1 \mathrm{equiv}$.) in THF $(10 \mathrm{~mL})$ was added dropwise. The reaction mixture was stirred at room temperature for $4 \mathrm{~d}$. The precipitated solid was collected by filtration and dissolved in a $12 \mathrm{mHCl} / \mathrm{methanol}(1: 1)$ mixture $(15 \mathrm{~mL})$, and the solution was heated to reflux with stirring for $24 \mathrm{~h}$. After the solution had cooled, distilled water was added $(10 \mathrm{~mL})$, and the solution was extracted with dichloromethane $(20 \mathrm{~mL})$. The $\mathrm{pH}$ of the aqueous layer was increased $(\mathrm{pH}>12)$ with $\mathrm{NaOH}$ pellets, and the product was extracted with dichloromethane $(3 \times 20$ $\mathrm{mL}$ ). The organic layers were dried with $\mathrm{MgSO}_{4}$, filtered, and concentrated to give $\mathbf{3}$ as a brown oil (yield $1.3 \mathrm{~g}, 87 \%) .{ }^{1} \mathrm{H} \mathrm{NMR}\left(\mathrm{CDCl}_{3}, 400 \mathrm{MHz}\right): \delta=2.5\left(\mathrm{~m}, 8 \mathrm{H}, \mathrm{CH}_{2 \mathrm{tacn}}\right), 2.62\left(\mathrm{~m}, 4 \mathrm{H}, \mathrm{m}, \mathrm{CH}_{2 \mathrm{tacn}}\right), 3.74(\mathrm{~s}, 2 \mathrm{H}$, $\mathrm{CH}_{2}$-py), 6.99 (dd, $\left.2 \mathrm{H}, 4.9, H_{\text {arom }}\right), 7.36\left(\mathrm{~d}, 2 \mathrm{H}, H_{\text {arom }}\right), 7.47\left(\mathrm{dd}, 2 \mathrm{H}, H_{\text {arom }}\right), 8.37\left(\mathrm{~d}, 2 \mathrm{H}, H_{\text {arom }}\right) \mathrm{ppm} .{ }^{13} \mathrm{C}$ NMR $\left(\mathrm{CDCl}_{3}, 100 \mathrm{MHz}\right): \delta=45.8,46.1,52.4\left(\mathrm{CH}_{2 \text { tacn }}\right), 63.0\left(\mathrm{CH}_{2}-\right.$ py $), 121.6,122.8,136.0,148.6\left(\mathrm{CH}_{\text {arom }}\right)$, $159.9\left(C_{\mathrm{q}}\right) \mathrm{ppm}$.

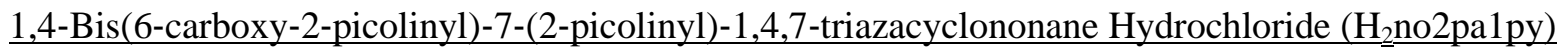

A solution of methyl 6-(chloromethyl)pyridine-2-carboxylate $(749 \mathrm{mg}, 4.0 \mathrm{mmol})$ in acetonitrile $(10 \mathrm{~mL})$ and sodium carbonate $(510 \mathrm{mg}, 4.8 \mathrm{mmol})$ were added to a solution of $\mathbf{3}(425 \mathrm{mg}, 1.9 \mathrm{mmol})$ in acetonitrile $(15 \mathrm{~mL})$, and the mixture was heated at $50{ }^{\circ} \mathrm{C}$ with stirring for $3 \mathrm{~d}$. After cooling, the solution was filtered, and the filtrate was concentrated under vacuum. The residue was purified by column chromatography on neutral alumina $\left(\mathrm{CH}_{2} \mathrm{Cl}_{2}\right.$ to $\left.\mathrm{CH}_{2} \mathrm{Cl}_{2} / \mathrm{EtOH}, 98: 2\right)$ to yield 1,4-bis(6-methoxycarbonyl-2-picolinyl)-7-(2picolinyl)-1,4,7-triazacyclononane (4) as a brown oil (700 mg, $70 \%) .{ }^{1} \mathrm{H}$ NMR $\left(\mathrm{CDCl}_{3}, 300 \mathrm{MHz}\right): \delta=2.83$ (br. s, $12 \mathrm{H}, \mathrm{CH}_{2 \text { tacn }}$ ), 3.81 (br. s, $2 \mathrm{H}, \mathrm{CH}_{2 \text { pyr }}$ ), 3.90 (s, $10 \mathrm{H}, \mathrm{OCH}_{3}+\mathrm{CH}_{2 \text { pic }}$ ), 7.08 (dd, $1 \mathrm{H}, H_{\text {arom-py }}$ ), 7.43 (d, $\left.1 \mathrm{H}, H_{\text {arom-py }}\right), 7.55$ (m, $\left.1 \mathrm{H}, H_{\text {arom-py }}\right), 7.58$ (m, $\left.4 \mathrm{H}, H_{\text {arom-pic }}\right), 7.73\left(\mathrm{~m}, 2 \mathrm{H}, H_{\text {arom-pic }}\right), 8.41$ (d, $\left.1 \mathrm{H}, H_{\text {arom-py }}\right)$ ppm. ${ }^{13} \mathrm{C}$ NMR $\left(\mathrm{CDCl}_{3}, 75.4 \mathrm{MHz}\right): \delta=52.7\left(\mathrm{CH}_{2 \mathrm{tan}}\right), 55.6\left(\mathrm{CH}_{3}\right), 64.4\left(\mathrm{CH}_{2}\right), 121.8,123.1,123.4,126.3$, 136.2, 137.1, 147.0, 148.7, $161.1\left(C_{\text {arom }}\right), 165.7\left(\mathrm{CO}_{2} \mathrm{CH}_{3}\right) \mathrm{ppm}$. This product was heated at $55^{\circ} \mathrm{C}$ in $6 \mathrm{~m} \mathrm{HCl}$ for $24 \mathrm{~h}$. After the concentration, the residue was precipitated with diethyl ether to yield $\mathrm{H}_{2}$ no2pa1py as a white powder (88\%). $\mathrm{C}_{26} \mathrm{H}_{30} \mathrm{~N}_{6} \mathrm{O}_{4} \cdot 4.5 \mathrm{H}_{2} \mathrm{O} \cdot 4.2 \mathrm{HCl}(724.76)$ : calcd. C 43.09, $\mathrm{H} \mathrm{6.01,} \mathrm{Cl} \mathrm{20.54,} \mathrm{N} \mathrm{11.60;}$ found C 42.98, H 5.74, $\mathrm{Cl} 20.47, \mathrm{~N} 11.38 .{ }^{1} \mathrm{H}$ NMR ( $\mathrm{D}_{2} \mathrm{O}, 300 \mathrm{MHz}$ ): $\delta=3.12$ (br. s, $4 \mathrm{H}, \mathrm{CH}_{2 \mathrm{tacn}}$ ), 3.60 (br. s, $\left.4 \mathrm{H}, \mathrm{CH}_{2 \text { tann }}\right), 3.91$ (s, $\left.4 \mathrm{H}, \mathrm{CH}_{2 \text { tacn }}\right), 4.25$ (s, $\left.2 \mathrm{H}, \mathrm{CH}_{2-\mathrm{py}}\right), 4.73$ (s, $\left.4 \mathrm{H}, \mathrm{CH}_{2 \text {-pic }}\right), 7.66$ (m, $\left.2 \mathrm{H}\right), 7.80(\mathrm{~m}, 2$ $\mathrm{H}), 7.99(\mathrm{~m}, 4 \mathrm{H}), 8.30(\mathrm{~m}, 1 \mathrm{H}), 8.52(\mathrm{~m}, 1 \mathrm{H}) \mathrm{ppm} .{ }^{13} \mathrm{C} \mathrm{NMR}\left(\mathrm{D}_{2} \mathrm{O}, 75.4 \mathrm{MHz}\right): \delta=50.0,53.4,55.1$ $\left(\mathrm{CH}_{2 \text { tacn }}\right), 56.9\left(\mathrm{CH}_{2}\right.$-py $), 63.1\left(\mathrm{CH}_{2}\right.$-pic $), 128.7,129.5,130.6,130.9,143.7,144.5\left(\mathrm{CH}_{\text {arom }}\right), 148.4\left(C_{\text {q-arom }}\right)$, $150.1\left(\mathrm{CH}_{\text {arom }}\right), 152.5,153.4\left(C_{\mathrm{q} \text {-arom }}\right), 169.2\left(\mathrm{CO}_{2} \mathrm{H}\right) \mathrm{ppm}$. 


\section{Copper(II) Complexes}

$\mathrm{Cu}\left(\mathrm{ClO}_{4}\right)_{2} \cdot 6 \mathrm{H}_{2} \mathrm{O}(100 \mathrm{mg}, 0.270 \mathrm{mmol})$ was added to a solution of $\mathrm{L}\left(\mathrm{L}=\right.$ no3py, $\mathrm{H}_{3}$ no3pa, $\mathrm{H}_{2}$ no1py2pa; 1 equiv.) in water $(15 \mathrm{~mL})$. The solution was adjusted slowly to $\mathrm{pH} 6$ by the addition of a dilute $\mathrm{NaOH}$ solution. The mixture was stirred with heating at $80{ }^{\circ} \mathrm{C}$ for $24 \mathrm{~h}$. The resulting blue solution was concentrated and dried under vacuum, the residue was added to $\mathrm{CH}_{3} \mathrm{CN}(10 \mathrm{~mL})$, and the insoluble matter was removed by filtration. This procedure was repeated three times. The clear solution was then concentrated and dried to yield the corresponding blue solid. HRMS (see the Supporting Information): $[\mathrm{Cu}(\mathrm{no} 3 \mathrm{py})]^{2+}$ : calcd. for $\mathrm{C}_{24} \mathrm{H}_{30} \mathrm{CuN}_{6}[\mathrm{M}]^{2+} 232.590848$, found 232.590783; $\left[\mathrm{Cu}\left(\mathrm{H}_{3} \text { no3pa }\right)\right]^{2+}$ : calcd. for $\mathrm{C}_{27} \mathrm{H}_{30} \mathrm{CuN}_{6} \mathrm{O}_{6}[\mathrm{M}]^{2+} 298.575592$, found 298.575773; calcd. for $\mathrm{C}_{27} \mathrm{H}_{29} \mathrm{CuN}_{6} \mathrm{O}_{6}[\mathrm{M}-\mathrm{H}]^{+}$596.142569, found 596.143318; $\left[\mathrm{Cu}\left(\mathrm{H}_{2} \text { no2pa1py) }\right]^{2+}\right.$ : calcd. for $\mathrm{C}_{26} \mathrm{H}_{30} \mathrm{CuN}_{6} \mathrm{O}_{4}[\mathrm{M}]^{2+} 276.580677$, found 276.580759; calcd. for $\mathrm{C}_{26} \mathrm{H}_{29} \mathrm{CuN}_{6} \mathrm{O}_{4}[\mathrm{M}-\mathrm{H}]^{+}$552.154077, found 552.153550; [Cu(Hno2py1pa) ${ }^{2+}$ was reported previously. ${ }^{[9]}$

\section{$\underline{\text { Equipment and Conditions for Potentiometric Studies }}$}

The potentiometric setup was described previously. ${ }^{[9]}$ The ionic strength of the experimental solution was kept at $0.10 \pm 0.01 \mathrm{~m}$ with $\mathrm{KNO}_{3}$, and the temperature was controlled at $25.0 \pm 0.1{ }^{\circ} \mathrm{C}$. The titrant was a $\mathrm{KOH}$ solution prepared at ca. $0.1 \mathrm{~m}$ from a commercial ampoule of analytical grade, and its accurate concentration was obtained through the application of the Gran method ${ }^{[28]}$ upon the titration of a standard $\mathrm{HNO}_{3}$ solution. The ligand solutions were prepared at ca. $2.0 \times 10^{-3} \mathrm{~m}$, and the $\mathrm{Cu}^{2+}$ and $\mathrm{Zn}^{2+}$ solutions were prepared at ca. $0.05 \mathrm{~m}$ from analytical-grade nitrate salts and standardized by complexometric titrations with ethylenediaminetetraacetic acid $\left(\mathrm{H}_{4}\right.$ edta). ${ }^{[29]}$ The sample solutions for titrations contained approximately 0.04 mmol of ligand in a volume of $30.0 \mathrm{~mL}$. In the complexation titrations, the metal cations were added at 0.9 and 1.8 equiv. of the ligand amount. In the competition titration of no3py, 1.0 equiv. of cyclam solution was used as a competitor in the presence of 1.0 equiv. of $\mathrm{Cu}^{2+}$ ions.

\section{$\underline{\text { Potentiometric Measurements }}$}

The electromotive forces of the sample solutions were measured after the calibration of the electrode through the titration of a standard $\mathrm{HNO}_{3}$ solution at $2.0 \times 10^{-3} \mathrm{~m}$. The $\left[\mathrm{H}^{+}\right]$of the solutions was determined through the measurement of the electromotive force of the cell, $E=E^{o \prime}+Q \log \left[\mathrm{H}^{+}\right]+E_{\mathrm{j}}$. The $\mathrm{pH}$ is defined as $\log \left[\mathrm{H}^{+}\right] . E^{0 \prime}$ and $Q$ were determined from the acidic $\mathrm{pH}$ region of the calibration curves. The liquid-junction potential, $E_{\mathrm{j}}$, was negligible under the experimental conditions used. The value of $K_{\mathrm{w}}=\left[\mathrm{H}^{+}\right]\left[\mathrm{OH}^{-}\right]$was found to be $10^{-13.78}$ through the titration of a solution of known $\left[\mathrm{H}^{+}\right]$at the same ionic strength in the alkaline $\mathrm{pH}$ region, and $E^{o r}$ and $Q$ were considered to be valid for the entire $\mathrm{pH}$ range. The protonation constants of cyclam and the thermodynamic stability constants of its copper(II) complex used in the competition-titration refinements were taken from the literature. ${ }^{[30]}$ Each in-cell titration consisted of $80-150$ equilibrium points in the range $\mathrm{pH}$ 2.0-11.5, and at least two replicate titrations were performed for each particular system. Back titrations were always performed at the end of each direct complexation titration to check if the equilibrium was attained throughout the entire $\mathrm{pH}$ range. A competition titration between no3py and cyclam with $\mathrm{Cu}^{2+}$ ions was prepared at 15 separate individual points in the $\mathrm{pH}$ range 5.0-10.0, and the samples for each point was closed in a vial under nitrogen. These points were measured under flushing with nitrogen after six weeks of stabilization (found by repeated measurement of one test vial over time) and used to determine accurately only the formation constant for the $[\mathrm{Cu}(\mathrm{no} 3 \mathrm{py})]^{2-}$ species, and the constants of the remaining species of this complex were determined from the in-cell titrations.

\section{$\underline{\text { Potentiometric Calculations }}$}

The potentiometric data were refined with the HYPERQUAD software, ${ }^{[31]}$ and speciation diagrams were plotted with the HySS software. ${ }^{[32]}$ The overall equilibrium constants $\beta_{i}{ }^{\mathrm{H}}$ and $\beta_{\mathrm{M}_{m} \mathrm{H}_{h} \mathrm{~L}_{l}}$ are defined by $\beta_{i}{ }^{\mathrm{H}}=$ $\left[\mathrm{H}_{h} \mathrm{~L}_{l}\right] /[\mathrm{H}]^{h}[\mathrm{~L}]^{l}$ and $\beta_{\mathrm{M}_{m} \mathrm{H}_{h} \mathrm{~L}_{l}}=\left[\mathrm{M}_{m} \mathrm{H}_{h} \mathrm{~L}_{l}\right] /[\mathrm{M}]^{m}[\mathrm{H}]^{h}[\mathrm{~L}]^{l}$. The differences, in log units, between the protonated 


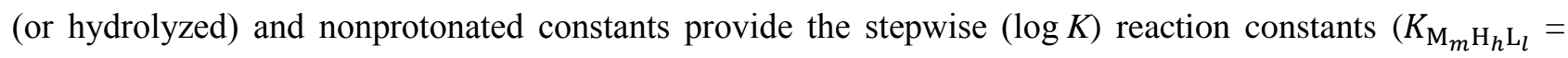
$\left.\left[\mathrm{M}_{m} \mathrm{H}_{h} \mathrm{~L}_{l}\right] /\left[\mathrm{M}_{m} \mathrm{H}_{h-1} \mathrm{~L}_{l}\right][\mathrm{H}]\right)$. The errors quoted are the standard deviations calculated by the fitting program from all of the experimental data for each system.

\section{$\underline{\text { Spectroscopic Studies }}$}

The Vis/NIR absorption spectra were measured with PerkinElmer Lambda 45 (visible) or Shimadzu UV3100 (NIR) spectrophotometers at $25{ }^{\circ} \mathrm{C}$. The samples of the complexes for the Vis/NIR measurements were prepared at ca. $2 \mathrm{~mm}$ by the addition of stoichiometric amounts of $\mathrm{Cu}\left(\mathrm{NO}_{3}\right)_{2}$ to ligand solutions followed by neutralization by the addition of a dilute $\mathrm{KOH}$ solution. The EPR spectra were recorded with a Bruker EMX 300 spectrometer operating at the X-band and equipped with a continuous-flow cryostat for liquid nitrogen. The samples for EPR spectroscopy were prepared in aqueous solutions at ca. $1 \mathrm{~mm}$ of complex and $1 \mathrm{~m}$ of $\mathrm{NaClO}_{4}$. The EPR spectra of the frozen aqueous solutions were acquired at $90 \mathrm{~K}$ at a microwave power of $2.0 \mathrm{~mW}$ and a frequency $(v)$ of $9.51 \mathrm{GHz}$. The experimental spectra were simulated with the SpinCount software. $^{[33]}$

\section{Electrochemistry Studies}

Cyclic voltammetry was performed in aqueous solution at room temp. with a BAS CV-50 W voltammetric analyzer operated with the BAS data acquisition software. The experiments were performed with a BAS MF1082 glass cell placed inside a BAS C-2 cell stand (Faraday cage). The three-electrode setup consisted of a reference $\mathrm{Ag} / \mathrm{AgCl}$ electrode (BAS MF-2052) filled with an aqueous $3 \mathrm{~m} \mathrm{NaCl}$ solution, a platinum wire auxiliary electrode (BAS MW-1032), and a glassy carbon working electrode (BAS MF-2012). Sample solutions of the copper(II) complexes at ca. $1 \mathrm{~mm}$ were prepared at neutral $\mathrm{pH}$ in $0.10 \mathrm{~m} \mathrm{NaOAc}$ supporting electrolyte. The sample solutions were degassed by bubbling $\mathrm{N}_{2}$ before all measurements and kept under an $\mathrm{N}_{2}$ stream during the measurements. Between each scan, the working electrode was electrocleaned by multicycle scanning in the supporting electrolyte solution, polished with alumina ( 1 and $0.05 \mu \mathrm{m})$, cleaned with water, and sonicated, according to standard procedures. Cyclic voltammograms with scan rates ranging from 10 to $200 \mathrm{mV} \mathrm{s}^{-1}$ were recorded in the region from 1000 to $-1500 \mathrm{mV}$, and the voltage was ramped from the starting potential towards a negative one and then back. In this potential range, the ligands were electrochemically inactive. The half-wave potentials, $E_{1 / 2}$, were obtained by averaging the anodic and cathodic peak potentials. All potential values are reported relative to the $\mathrm{Ag} / \mathrm{AgCl}$ reference electrode in aqueous $3 \mathrm{~m} \mathrm{NaCl}$.

\section{$\underline{\text { Computational Methods }}$}

Full geometry optimizations of the $[\mathrm{Cu}(\text { no3py })]^{2+},[\mathrm{Cu}($ no2papy $)]$, and $[\mathrm{Cu}(\text { no3pa })]^{-}$systems in aqueous solution were performed by unrestricted DFT calculations within the hybrid meta-generalized gradient approximation (meta-GGA) with the TPSSh exchange-correlation functional ${ }^{[34]}$ and the Gaussian 09 package (revision D.01). ${ }^{[35]}$ In these calculations, we used the standard Ahlrichs valence triple- $\xi$ basis set including polarization functions (TZVP). ${ }^{[36]}$ Solvent effects were included by using the polarizable continuum model (PCM), in which the solute cavity is built as an envelope of spheres centered on atoms or atomic groups with appropriate radii. In particular, we used the integral equation formalism (IEFPCM) variant, as implemented in Gaussian $09 .{ }^{[37]}$ No symmetry constraints were imposed during the optimizations. The stationary points found on the potential energy surfaces as a result of geometry optimizations were verified as energy minima rather than saddle points through frequency analysis. The Gibbs free energies were obtained at $T=298.15 \mathrm{~K}$ within the harmonic approximation. The default values for the integration grid (75 radial shells and 302 angular points) and the self-consistent field (SCF) energy convergence criteria $\left(10^{-8}\right)$ were used in all calculations. The calculations of the $g$ and $A$ tensors were performed with the ORCA program package (Version 3.0.1 ${ }^{[38]}$ and the methodology developed by Neese. ${ }^{[39]}$ The TPSSh functional was used in these calculations, as it was shown to be at least as accurate as or better than the B3LYP functional for the 
prediction of hyperfine structure and significantly superior to the nonhybrid TPSS variant. ${ }^{[40]}$ The effect that the amount of nonlocal exchange has on the calculated $g$ and $A$ tensors was assessed by performing calculations with the TPSS0 functional, ${ }^{[4]}$ which is a $25 \%$ exchange version of TPSSh ( $10 \%$ exchange) that provides improved energetics. ${ }^{[42]}$ The geometries of the complexes optimized as described above with the Gaussian code were employed for the calculations of the EPR parameters. The center of the electronic charge was taken as the origin for the calculation of the $g$ tensor, which is a gauge-dependent property. The different contributions to the $g$ tensor include the relativistic mass correction, the diamagnetic spin-orbit term, and the paramagnetic spin-orbit term. The $A$ tensor was calculated as a sum of three terms: (a) the isotropic Fermi contact (FC) term, (b) the spin-dipolar (SD) term, and (c) the spin-orbit coupling (SOC) term. The spinorbit contributions to the hyperfine coupling constants and $g$ values were computed by the spin-orbit mean field approach (SOMF) with the one-center approximation to the exchange term $[\operatorname{SOMF}(1 \mathrm{X})] .{ }^{[43]}$ The basis sets used for the calculations of the EPR parameter were the aug-cc-pVTZ-J basis set of Sauer for $\mathrm{Cu}^{[44]}$ and the Ahlrichs TZVP basis set for all other atoms. ${ }^{[36]}$ The aug-cc-pVTZ-J basis set, which is described by a $(25 \mathrm{~s} 17 \mathrm{p} 10 \mathrm{~d} 3 \mathrm{f} 2 \mathrm{~g}) /[17 \mathrm{~s} 10 \mathrm{p} 7 \mathrm{~d} 3 \mathrm{f} 2 \mathrm{~g}]$ contraction scheme was developed specifically for the calculation of EPR parameters and includes four tight s-, one tight p-, and one tight d-type function to better describe the core region. The RIJCOSX approximation ${ }^{[45]}$ was used to speed up the calculations of the EPR parameters with the Def2-TZVPP/JK ${ }^{[46]}$ auxiliary basis set as constructed automatically by ORCA. The convergence tolerances and integration accuracies of the calculations were increased from the defaults with the available TightSCF and Grid5 options. Solvent effects (water) were taken into account with the conductor-like screening model (COSMO), as implemented in ORCA. ${ }^{[4]}$

\section{Acknowledgements}

R. T. and V. P. acknowledge the CNRS (Centre National de la Recherche Scientifique), the French Ministère de la Recherche (PhD fellowship of A. G.), the Région Bretagne (PhD fellowship of M. R.) and Brest University. L. M. P. L. and R. D. are thankful for the financial support from FEDER funds through COMPETE2020 - Programa Operacional Competitividade e Internacionalização (POCI) for project LISBOA-01-0145-FEDER-007660 (Microbiologia Molecular, Estrutural e Celular) and by national funds through the FCT (Fundação para a Ciência e a Tecnologia). L. M. P. L. also thanks the FCT for a postdoctoral fellowship (SFRH/BPD/73361/2010). C. P.-I and D. E.-G. thank the Centro de Supercomputación de Galicia (CESGA) for providing the computer facilities.

\section{References}

[1] a) P. J. Blower, Dalton Trans., 2015, 44, 4819-4844; b) C. F. Ramogida and C. Orvig, Chem. Commun., 2013, 49, 4720-4739.

[2] a) E. W. Price and C. Orvig, Chem. Soc. Rev., 2014, 43, 260-290; b) D. Brasse and A. Nonat, Dalton Trans., 2015, 44, 4845-4858.

[3] B. M. Zeglis, J. L. Houghton, M. J. Evans, N. Viola-Villegas and J. S. Lewis, Inorg. Chem., 2014, 53, 1880-1899.

[4] a) Y. Gai, L. Sun, W. Hui, Q. Ouyang, C. J. Anderson, G. Xiang, X. Ma and D. Zeng, Inorg. Chem., 2016, 55, 6892-6901; b) N. Wu, C. S. Kang, I. Sin, S. Ren, D. Liu, V. C. Ruthengael, M. R. Lewis and H. S. Chong, J. Biol. Inorg. Chem., 2016, 21, 177-184; c) A. J. Chang, R. Sohn, Z. H. Lu, J. M. Arbeit and S. E. Lapi, PLos One, 2013, 8, e58949; d) Y. Zhang, H. Hong, J. W. Engle, J. Bean, Y. Yang, B. R. Leigh, T. E. Barnhart and W. Cai, PLoS One, 2011, e28005. 
[5] T. J. Wadas, E. H. Wong, G. R. Weisman and C. J. Anderson, Chem. Rev., 2010, 110, 2858-2902.

[6] J. Šimeček, M. Schulz, J. Notni, J. Plutnar, V. Kubíček, J. Havlíčková and P. Hermann, Inorg. Chem., 2012, 51, 577-590.

[7] J. Šimeček, O. Zemek, P. Hermann, H. J. Wester and J. Notni, ChemMedChem, 2012, 7, 1375-1378.

[8] G. Gasser, L. Tjioe, B. Graham, M. J. Belousoff, S. Juran, M. Walther, J. U. Künstler, R. Bergmann, H. Stephan and L. Spiccia, Bioconjugate Chem., 2008, 19, 719-730.

[9] M. Roger, L. M. P. Lima, M. Frindel, C. Platas-Iglesias, J. F. Gestin, R. Delgado, V. Patinec and R. Tripier, Inorg. Chem., 2013, 52, 5246-5259.

[10] M. Mato-Iglesias, A. Roca-Sabio, Z. Pálinkás, D. Esteban-Gómez, C. Platas-Iglesias, É. Tóth, A. de Blas and T. Rodríguez-Blas, Inorg. Chem., 2008, 47, 7840-7851.

[11] a) L. Christiansen, D. N. Hendrickson, H. Toftlund, S. R. Wilson and C. L. Xie, Inorg. Chem., 1986, 25, 2813-2818; b) K. Wieghardt, E. Schoeffmann, B. Nuber and J. Weiss, Inorg. Chem., 1986, 25, 4877-4883.

[12] C. Gateau, M. Mazzanti, J. Pécaut, F. A. Dunand and L. Helm, Dalton Trans., 2003, 2428-2433.

[13] M. J. Van der Merwe, J. C. A. Boeyens and R. D. Hancock, Inorg. Chem., 1985, 24, 1208-1213.

[14] a) A. Rodríguez-Rodríguez, Z. Garda, E. Ruscsák, D. Esteban-Gómez, A. de Blas, T. Rodríguez-Blas, L. M. P. Lima, M. Beyler, R. Tripier, G. Tircsó and C. Platas-Iglesias, Dalton Trans., 2015, 44, 5017-5031;

b) Y. Bretonniere, M. Mazzanti, J. Pecaut, F. A. Dunand and A. E. Merbach, Inorg. Chem., 2001, 40, 67376745.

[15] R. Delgado, Y. Sun, R. J. Motekaitis and A. E. Martell, Inorg. Chem., 1993, 32, 3320-3326.

[16] A. Bevilacqua, R. I. Gelb, W. B. Hebard and L. J. Zompa, Inorg. Chem., 1987, 26, 2699-2706.

[17] G. Nocton, A. Nonat, C. Gateau and M. Mazzanti, Helv. Chim. Acta, 2009, 92, 2257-2273.

[18] L. M. P. Lima, R. Delgado, M. G. B. Drew, P. Brandão and V. Felix, Dalton Trans., 2008, 6593-6608.

[19] C. F. G. C. Geraldes, M. P. M. Marques, B. Castro and E. Pereira, Eur. J. Inorg. Chem., 2000, 559-565.

[20] a) E. J. Corey and J. C. Bailar, J. Am. Chem. Soc., 1959, 81, 2620-2629; b) J. K. Beattie, Acc. Chem. Res., 1971, 4, 253-259.

[21] a) P. Hermann, J. Kotek, V. Kubicek and I. Lukes, Dalton Trans., 2008, 3027-3047; b) D. Parker, R. S. Dickins, H. Puschmann, C. Crossland and J. A. K. Howard, Chem. Rev., 2002, 102, 1977-2010.

[22] W. Han, Z. D. Wang, C. Z. Xie, Z. Q. Liu, S. P. Yan, D. Z. Liao, Z. H. Jiang and P. Cheng, J. Chem. Crystallogr., 2004, 34, 495-500.

[23] W. M. Ames and S. C. Larsen, J. Phys. Chem. A, 2009, 113, 4305-4312.

[24] S. P. de Visser, M. G. Quesne, B. Martin, P. Comba and U. Ryde, Chem. Commun., 2014, 50, $262-282$.

[25] M. Regueiro-Figueroa, L. M. P. Lima, V. Blanco, D. Esteban-Gómez, A. de Blas, T. Rodríguez-Blas, R. Delgado and C. Platas-Iglesias, Inorg. Chem., 2014, 53, 12859-12869.

[26] D. N. Pandya, A. V. Dale, J. Y. Kim, H. Lee, Y. S. Ha, G. I. An and J. Yoo, Bioconjugate Chem., 2012, 23, 330-335. 
[27] K. S. Woodin, K. J. Heroux, C. A. Boswell, E. H. Wong, G. R. Weisman, W. Niu, S. A. Tomellini, C. J. Anderson, L. N. Zakharov and A. L. Rheingold, Eur. J. Inorg. Chem., 2005, 4829-4833.

[28] F. J. C. Rossotti and H. Rossotti, J. Chem. Educ., 1965, 42, 375-378.

[29] G. Schwarzenbach and W. Flaschka, in: Complexometric Titrations, Methuen \& Co, London, 1969.

[30] R. J. Motekaitis, B. E. Rogers, D. E. Reichert, A. E. Martell and M. J. Welch, Inorg. Chem., 1996, 35, 3821-3827.

[31] P. Gans, A. Sabatini and A. Vacca, Talanta, 1996, 43, 1739-1753.

[32] L. Alderighi, P. Gans, A. Ienco, D. Peters, A. Sabatini and A. Vacca, Coord. Chem. Rev., 1999, 184, 311-318.

[33] D. Petasis and M. Hendrich, Methods Enzymol., 2015, 563, 171-208.

[34] J. M. Tao, J. P. Perdew, V. N. Staroverov and G. E. Scuseria, Phys. Rev. Lett., 2003, 91, 146401.

[35] M. J. Frisch, G. W. Trucks, H. B. Schlegel, G. E. Scuseria, M. A. Robb, J. R. Cheeseman, G. Scalmani, V. Barone, B. Mennucci, G. A. Petersson, H. Nakatsuji, M. Caricato, X. Li, H. P. Hratchian, A. F. Izmaylov, J. Bloino, G. Zheng, J. L. Sonnenberg, M. Hada, M. Ehara, K. Toyota, R. Fukuda, J. Hasegawa, M. Ishida, T. Nakajima, Y. Honda, O. Kitao, H. Nakai, T. Vreven, J. A. MontgomeryJr, J. E. Peralta, F. Ogliaro, M. Bearpark, J. J. Heyd, E. Brothers, K. N. Kudin, V. N. Staroverov, R. Kobayashi, J. Normand, K. Raghavachari, A. Rendell, J. C. Burant, S. S. Iyengar, J. Tomasi, M. Cossi, N. Rega, J. M. Millam, M. Klene, J. E. Knox, J. B. Cross, V. Bakken, C. Adamo, J. Jaramillo, R. Gomperts, R. E. Stratmann, O. Yazyev, A. J. Austin, R. Cammi, C. Pomelli, J. W. Ochterski, R. L. Martin, K. Morokuma, V. G. Zakrzewski, G. A. Voth, P. Salvador, J. J. Dannenberg, S. Dapprich, A. D. Daniels, Ö. Farkas, J. B. Foresman, J. V. Ortiz, J. Cioslowski and D. J. Fox, Gaussian 09, revision D.01, Gaussian, Inc., Wallingford, CT, 2009.

[36] a) A. Schäfer, H. Horn and R. Ahlrichs, J. Chem. Phys., 1992, 97, 2571-2577.; b) A. Schäfer, C. Huber and R. Ahlrichs, J. Chem. Phys., 1994, 100, 5829-5835.

[37] J. Tomasi, B. Mennucci and R. Cammi, Chem. Rev., 2005, 105, 2999-3093.

[38] The ORCA program system: F. Neese, Wiley Interdiscip. Rev.: Comput. Mol. Sci., 2012, 2, 73-78.

[39] a) F. Neese, J. Chem. Phys., 2003, 118, 3939-3948; b) F. Neese, J. Chem. Phys., 2001, 115, 1108011096; c) F. Neese, J. Phys. Chem. A, 2001, 105, 4290-4299.

[40] S. Kossmann, B. Kirchner and F. Neese, Mol. Phys., 2007, 105, 2049-2070.

[41] S. Grimme, J. Phys. Chem. A, 2005, 109, 3067-3077.

[42] a) M. K. Kesharwani and J. M. L. Martin, Theor. Chem. Acc., 2014, 133, 1452; b) A. Marzouk, B. Madebène and M. E. Alikhani, J. Phys. Chem. A, 2013, 117, 4462-4471.

[43] F. Neese, J. Chem. Phys., 2005, 122, 034107.

[44] E. D. Hedegard, J. Kongsted and S. P. A. Sauer, J. Chem. Theory Comput., 2011, 7, 4077-4087.

[45] a) F. Neese, F. Wennmohs, A. Hansen and U. Becker, Chem. Phys., 2009, 356, 98-109; b) R. Izsak and F. Neese, J. Chem. Phys., 2011, 135, 144105; c) T. Petrenko, S. Kossmann and F. Neese, J. Chem. Phys., 2011, 134, 054116; d) S. Kossmann and F. Neese, Chem. Phys. Lett., 2009, 481, 240-243. 
[46] F. Weigend and R. Ahlrichs, Phys. Chem. Chem. Phys., 2005, 7, 3297-3305.

[47] S. Sinnecker, A. Rajendran, A. Klamt, M. Diedenhofen and F. Neese, J. Phys. Chem. A, 2006, 110, 2235-2245.

${ }^{\mathrm{i}}$ Supporting information for this article is available online: https://doi.org/10.1002/ejic.201700176. 